\title{
Immunoneutralization of vascular endothelial growth factor inhibits pregnancy establishment in the rhesus monkey (Macaca mulatta)
}

\author{
J Sengupta, P G L Lalitkumar, A R Najwa, D S Charnock-Jones ${ }^{1}$, A L Evans ${ }^{2}$, A M Sharkey², \\ S K Smith ${ }^{1}$ and D Ghosh \\ Department of Physiology, All India Institute of Medical Sciences, New Delhi 110029, India, ${ }^{1}$ Department of \\ Obstetrics and Gynecology, University of Cambridge, Cambridge CB2 2SW, UK and ${ }^{2}$ Department of Pathology, \\ University of Cambridge, Cambridge CB2 1QP, UK
}

Correspondence should be addressed to D Ghosh; Email: dghosh@aiims.ac.in

S K Smith is now at Faculty of Medicine, Imperial College London, London SW7 2 AZ, UK

\begin{abstract}
Maternal endometrial vascular endothelial growth factor (VEGF) is considered important in blastocyst implantation. However, there is no direct evidence to support this conjecture in the primate. In the present study, we have examined this hypothesis by testing whether immunoneutralization of VEGF during the peri-implantation stage of gestation affects embryo implantation in the rhesus monkey. Adult female animals $(n=36)$ during mated ovulatory cycles were randomly assigned to one of the experimental groups treated subcutaneously with either isotype-matched mouse immunoglobulin (group 1: control, $n=8$ ) or monoclonal mouse antibody against VEGF-A (anti-VEGF Mab; group 2: $10 \mathrm{mg}$ on day 5 after ovulation, $n=8$; group 3: $20 \mathrm{mg}$ on day 5 after ovulation, $n=8$; group 4: $10 \mathrm{mg}$ on day 10 after ovulation, $n=4$; group 5: $10 \mathrm{mg}$ on days 5 and 10 after ovulation, $n=8$ ). AntiVEGF Mab-treated animals in groups 2-4 did not show any marked inhibition in pregnancy establishment. On pooled analysis, however, anti-VEGF Mab administration in groups 2-5 $(n=28)$ resulted in a significant $(P<0.04)$ decline in the number of viable term pregnancy when compared with control animals. The observed difference was explained by the fact that $10 \mathrm{mg}$ anti-VEGF Mab given to each animal on days 5 and 10 after ovulation in group $5(n=8)$ inhibited pregnancy establishment significantly $(\boldsymbol{P}<\mathbf{0 . 0 2})$ when compared with control group 1. There was no significant change in serum concentrations of estradiol-17 $\beta$, progesterone, and free VEGF among groups. Furthermore, animals treated with anti-VEGF Mab ( $n=8)$ as in group 5 revealed marked decrease in immunoreactive VEGF, fms-like tyrosine kinase-1, and kinase-insert domain region in trophoblast cells associated with shallow uterine invasion on day 13 of gestation when compared with samples from control group animals $(n=8)$. Thus, VEGF action is required for successful blastocyst implantation in the rhesus monkey.

Reproduction (2007) 133 1199-1211
\end{abstract}

\section{Introduction}

Blastocyst implantation in the rhesus monkey is initiated around days 7-9 after ovulation and fertilization. Local signaling between the pre-implantation stage embryo and the endometrium is likely to play a critical role ensuring synchronous growth and differentiation of embryonic and endometrial cells in a time- and stagespecific manner (Lopata 1996, Ghosh \& Sengupta 1998). Of various factors, vascular endothelial growth factor-A (VEGF-A), a potent regulator of the integrity, permeability, and proliferation of blood vessels (Ferrara \& Smith 1997), appears to be important in embryoendometrium interaction at blastocyst implantation in rodents (Rabbani \& Rogers 2001, Rockwell et al. 2002). In the human and the monkey, menstrual cycledependent changes in endometrial VEGF-A have been reported (Shifren et al. 1996, Nayak \& Brenner 2002).

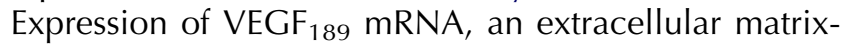
bound isoform, was found to be dependent on progesterone action in cynomolgus monkey (Greb et al. 1997) and in human uterus (Ancelin et al. 2002). The endometrial expression of both VEGF mRNA and protein reportedly occurs during the mid-secretory stage in the human (Charnock- Jones et al. 1993, Li et al. 1994). The fms-like tyrosine kinase- 1 (FLT-1 and VEGFR1) and the kinase-insert domain region (KDR 
and VEGFR2) are high-affinity tyrosine kinase receptors for VEGF. They are co-expressed in capillaries during the mid-secretory period and this observation correlates well with the increased microvascular density and vascular permeability observed at this time (Krussel et al. 1999, Meduri et al. 2000). However, VEGF is secreted preferentially into lumina of endometrial glands in polarized human endometrial cell cultures, suggesting that apically secreted VEGF may also function as an endometrial signal for blastocyst development and/or implantation (Hornung et al. 1998). The expression of VEGF mRNA and its protein has been detected in trophoblast cells and in maternal glandular and vascular compartments of lacuna and early villous stages of implantation-placentation in the rhesus monkey (Ghosh et al. 2000). Failure of pregnancy in the rhesus monkey following early luteal phase, mifepristone treatment was reportedly associated with endometrial dysynchronization along with downregulation in expression and secretion of VEGF (Ghosh et al. 1998).

Taken together, this evidence suggests two potential roles for endometrial VEGF during implantation: a role in endometrial blood vessels and the establishment of receptivity and also a role in blastocyst implantation and trophoblast invasion. However, to date, there has been no direct evidence to show that VEGF is essential for successful implantation in the primate. In the present study, we have examined this hypothesis by testing whether immunoneutralization of VEGF-A during the receptive preparation of endometrium (day 5 after ovulation) and/or the implantation window (day 10 after ovulation) of gestational cycle affects embryo implantation in the rhesus monkey.

\section{Materials and Methods}

\section{Animals and experimental procedures}

Proven-fertile, adult female rhesus monkeys $(n=40)$ showing two consecutive menstrual cycles of normal length (26-30 days) were placed for mating with male monkeys of proven fertility during cycle days 8-16. Peripheral blood samples were collected for hormone assays and vaginal smears were checked daily for the presence of spermatozoa. Ovulation was detected by rapid assay from the daily serum profiles of estradiol $\left(E_{2}\right)$ and progesterone $(\mathrm{P})$, as described in the following section. The assumed day of ovulation was taken $24 \mathrm{~h}$ after the day of peak rise of serum $E_{2}$ and had showed clearly detectable serum $\mathrm{P}$ level. The details have been given elsewhere (Ghosh \& Sengupta 1993). Vaginal smears were immediately scored on a scale of 4: poor, good, very good, and excellent based on number, viability, and forward movement of spermatozoa. Four female monkeys were removed from this study when they had either failed to ovulate and/or sperm profiles were found to be consistently poor. Thus, female monkeys $(n=36)$ showing positive ovulation and very good to excellent vaginal sperm profiles were randomly assigned to one of the experimental groups (groups 1-5), and received s.c. injection of either isotype-matched mouse immunoglobulin (IgG) or monoclonal mouse antibody against VEGF (anti-VEGF Mab). The doses and timings of the different treatment regimes are shown in Table 1. All injections were administered between 1000 and $1030 \mathrm{~h}$ on the assigned day. Sera were obtained from daily blood samples collected by venipuncture from experimental animals from cycle days 8 to 40 , or the onset of next menstrual cycle and stored at $-70{ }^{\circ} \mathrm{C}$ till their use in immunoassays to determine the peripheral concentrations of $\mathrm{E}_{2}, \mathrm{P}$, and monkey chorionic gonadotropin (mCG) as described below to monitor the pregnancy outcome for animals in groups 1-5. The pregnancy establishment was checked by per-rectum uterine palpation as described previously (Ghosh et al. 1997) and the pregnant animals were routinely monitored until they delivered. The normal length of gestation in monkeys of our colony is $170 \pm 15$ (mean \pm s.D.) days.

An additional 16 ovulated and successfully mated females were classified into two groups, eight in each group, and they were treated with either control mouse isotype-matched IgG (like group 1 in Table 2), or antiVEGF Mab (like group 5 in Table 1). They were laparotomized under ketamine anesthesia $(12 \mathrm{mg} / \mathrm{kg}$ body weight; Parke Davis, Mumbai, India) on day 13 post-ovulation for performing hysterectomy under aseptic conditions to collect implantation sites and maternal endometrium (Sengupta et al. 2003). Tissues were fixed and processed for histology and immunohistochemistry to localize the site of expressions of VEGF and its receptors, KDR and FLT-1 in fetal and maternal compartments. Endothelial cells were stained for von Willebrand factor (VWF)-associated antigen and platelet-endothelial cell adhesion molecule (PECAM, CD31), and cytokeratin, neural cell adhesion molecule (NCAM, CD56), and PECAM were used for the immunolocalization of trophoblast cells as described previously (Sengupta \& Ghosh 2002, Sengupta et al. 2003, Ghosh et al. 2004).

The Primate Research Facility of the All India Institute of Medical Sciences provided routine animal care and management. The present study was conducted with the approval of the Ethics Committee for the Use of NonHuman Primates in Biomedical Research of the All India Institute of Medical Sciences.

\section{Anti-VEGF Mab and isotype-matched IgG}

A neutralizing Mab directed against VEGF-A was produced by immunization of mice with recombinant human VEGF-A $A_{165}$ conjugated to keyhole limpet hemocyanin as described previously (Sharkey et al. 2005). Both anti-VEGF-A antibody and control IgG 
Table 1 Effects subcutaneous administration of isotype matched mouse immunoglobulin (control lgG) or mouse monoclonal antibody against vascular endothelial growth factor (anti-VEGF Mab) during peri-implantation stage of mated ovulated cycles of rhesus monkeys on the pregnancy outcome.

\begin{tabular}{|c|c|c|c|c|c|c|}
\hline \multirow[b]{2}{*}{$\begin{array}{l}\text { Group } \\
(n)\end{array}$} & \multirow[b]{2}{*}{ Treatment s.c. (mg) } & \multirow[b]{2}{*}{$\begin{array}{c}\text { Day of treatment } \\
\text { p.ov }\end{array}$} & \multicolumn{3}{|c|}{ Number of animals showing } & \multirow{2}{*}{$\begin{array}{c}\text { Number of animals failed to be } \\
\text { pregnant (length of menstrual } \\
\text { cycle, days) }\end{array}$} \\
\hline & & & $\begin{array}{l}\text { Biochemical } \\
\text { pregnancy }^{\mathrm{a}}\end{array}$ & $\begin{array}{c}\text { Term } \\
\text { pregnancy }\end{array}$ & $\begin{array}{l}\text { Aborted } \\
\text { pregnancy }\end{array}$ & \\
\hline $1(8)$ & Control IgG $(10,10)$ & 5 and 10 & 6 & 6 & 0 & $2(27,31)$ \\
\hline $2(8)$ & Anti-VEGF Mab (10) & 5 & 3 & 3 & 0 & $5(26,28,28,31,32)$ \\
\hline $3(8)$ & Anti-VEGF Mab (20) & 5 & 5 & 3 & $2^{b}$ & $3(27,31,31)$ \\
\hline $4(4)$ & Anti-VEGF Mab (10) & 10 & 4 & 3 & $1^{\mathrm{c}}$ & 0 \\
\hline $5(8)$ & Anti-VEGF Mab $(10,10)$ & 5 and 10 & 1 & $0^{* *}$ & $1^{\mathrm{d}}$ & $7^{*}(27,29,29,29,30,32)$ \\
\hline
\end{tabular}

p.ov., after ovulation. ${ }^{* *} P<0.01, * P<0.02$ as compared to group 1 .

a Based on detectable mCG. ${ }^{b}$ Days 18 and 133 of gestation, respectively. ${ }^{\mathrm{c}}$ Day 139 of gestation. ${ }^{\mathrm{d}}$ Day 135 of gestation.

(isotype-matched, $\lg \mathrm{G} 1 \kappa$ ) were purified by binding to protein $\mathrm{G}$ sepharose, desalting (Centricon ultrafiltration) and lyophilized in $10 \mathrm{mg}$ lots. The neutralizing activity of the antibody was demonstrated using a bioassay in which iodinated VEGF binds to its receptors on endothelial cells as described previously (Sharkey et al. 2005).

\section{Estimation of serum concentrations of $E_{2}, P, m C G$, $V E G F$, and mouse IgG}

Serum concentrations of $E_{2}$ and $P$ were measured by competitive ELISA using reagents and protocols provided by DRG International Inc. (NJ, USA). The results were analyzed using log-logit transformation of the data and the hormone values were log transformed for further analysis. The assay sensitivity was $4.6 \mathrm{pg} / \mathrm{ml}$ and $0.5 \mathrm{ng} / \mathrm{ml}$ for $E_{2}$ and $P$ respectively; intra- and interassay coefficients of variations for $E_{2}$ assays were 6.3 and $7.8 \%$ respectively, and those for $\mathrm{P}$ assays were 4.8 and $6.5 \%$ respectively.

Serum concentration of mCG was measured by the sandwich enzyme-linked immunoabsorbent technique reported earlier (Ghosh et al. 1997). The Mab (Mab 518 B7) was generated against bovine luteinizing hormone (LH) and it was horse radish peroxidase (HRP) conjugated, and the polyclonal antiserum was raised in rabbits against human chorionic gonadotropin (hCG cr-121). Positive and negative controls were added to each plate and all the samples were assayed in one run. The assay sensitivity for mCG was $0.03 \mathrm{ng} / \mathrm{ml}$.

Serum concentrations of free VEGF antigen in animals of the different groups were measured to discern if antiVEGF Mab administration affected systemic VEGF levels. Serum levels of free VEGF were estimated using ELISA kit from R\&D Systems (Minneapolis, MN, USA) according to manufacturer's instruction. A seven-point standard curve was plotted using twofold serial dilution to calculate the concentration of free VEGF in the sample. The assay sensitivity for VEGF was found to be $65 \mathrm{pg} / \mathrm{ml}$; intra- and inter-assay coefficients of variations for VEGF antigen were 3.6 and $5.1 \%$ respectively.
Serum concentrations of immunoreactive mouse IgGs, the anti-VEGF mouse Mab (anti-VEGF Mab), and isotype-matched control mouse IgG, were estimated using a mouse IgG ELISA kit from Roche diagnostics $\mathrm{GmbH}$ (Manheim, Germany) according to manufacturer's instructions. Standards, antibodies, solutions, and reagents for this assay were supplied by the manufacturer. Serum samples collected from each animal before treatment with isotype-matched IgG or anti-VEGF Mab were used as internal negative baseline controls. The assay sensitivity for anti-mouse $\operatorname{lgG}$ was $10 \mathrm{ng} \mathrm{lgG} / \mathrm{ml}$; intra- and inter-assay coefficients of variations for mouse $\operatorname{lgG}$ were 2.7 and $5.9 \%$ respectively.

\section{Serum profiles and clearance kinetics of serum mouse IgG}

Data for mouse IgG concentration in serum versus time for rhesus monkeys injected subcutaneously with either control IgG or anti-VEGF Mab were analyzed using standard formulations for one compartment model (Shargel \& Yu 1999). The clearance rate constant $(k)$, time to reach maximal level of concentration $\left(T_{\max }\right)$, and the concentration of antibody at this level $\left(C_{\max }\right)$, area under curve $(A \cup C)$ of antibody, and mean resident time (MRT) were subsequently estimated using standard methods (Shargel \& Yu 1999).

Table 2 Characteristics of primary antibodies used for immunohistochemistry.

\begin{tabular}{llcl}
\hline Antigen & $\begin{array}{c}\text { Specification of } \\
\text { antisera }\end{array}$ & Dilution $(\mu \mathrm{g} / \mathrm{ml})$ & Source \\
\hline VEGF & Goat IgG & 1.0 & R\&D Systems \\
FLT-1 & Goat IgG & 2.5 & R\&D Systems \\
KDR & Goat IgG & 1.5 & R\&D Systems \\
Cytokeratin & Mouse IgG & 1.8 & DAKO \\
Vimentin & Mouse IgG & 4.5 & DAKO \\
VWF & Rabbit IgG & 25.0 & DAKO \\
NCAM (CD56) & Mouse IgG & 1.0 & NeoMarkers \\
PECAM (CD31) & Mouse IgG & 2.5 & NeoMarkers \\
\hline
\end{tabular}

R\&D Systems, Minneapolis, MN, USA. DAKO, Glostrup, Denmark. NeoMarkers, Fremont, CA, USA. 


\section{Endometrial tissue/implantation stage morphology and immunohistochemistry}

Sixteen females were successfully mated during days 8-16 of their ovulatory cycles and eight were treated with control mouse isotype-matched IgG (like group 1 in Table 1), and the other eight females were treated with anti-VEGF Mab (like group 5 in Table 1). On day 13 post-ovulation, endometrial tissue from the uterine corpus was removed by hysterectomy, washed in fresh ice-cold PBS $(\mathrm{pH} 7.2)$ to remove adhering blood, and immediately fixed in neutral phosphate-buffered paraformaldehyde $(4 \%, w / v)$. The samples were embedded in paraffin wax and examined for normal histology as described previously (Sengupta et al. 2003, Ghosh et al. 2004). Paraffin sections $(5 \mu \mathrm{m})$ were employed for hematoxylin staining and for immunohistochemical localization of VEGF, FLT-1, and KDR. Trophoblast cells and plaque-epithelial cells were identified by immunostaining with antibody against cytokeratin, invasive extravillous (interstitial) trophoblast cells were identified from immunolocalization of NCAM (CD56) and PECAM (CD31), and endothelial cells by immunostaining with antibody against PECAM and VWF as described elsewhere (Sengupta \& Ghosh 2002, Sengupta et al. 2003, Ghosh et al. 2004). The sources of antibodies and dilutions of stock antibodies were optimized based on four to five points titration as shown in Table 2. Final visualization was achieved using the $A B C$ peroxidase kits (Vector Laboratories, Burlingame, CA, USA) and freshly prepared diaminobenzidine hydrochloride with hydrogen peroxide (Sigma Chemical). Specificity of the antibodies was assessed by omitting primary antibodies, immunosorption of primary antibodies with target peptides, replacing primary antibodies with unrelated IgG from same species and other species, omitting secondary antibodies, and replacing secondary antibody with unrelated labeled IgGs from same species and other species. Labeled and unlabeled IgGs, non-immune sera, and other supplies were purchased from Vector Laboratories and Sigma Chemical.

The sections $(5 \mu \mathrm{m})$ of primary implantation sites and endometrial tissue samples after hematoxylin staining and immunostaining were independently examined by three investigators and microphotographs were taken using a Leica DMRBE microscope attached with a Leitz DMRD microphotograph processor and a digital camera.

\section{Statistical analysis}

The pregnancy outcome in different groups was analyzed using the Fisher's exact probability test (Zar 1999). The AUCs for serum $E_{2}, P, V E G F$, and mouse $\lg G$, and $k, C_{\text {max }}$ and $T_{\max }$ for mouse $\operatorname{lgG}$ in monkey serum samples, and body weights and crown-rump lengths of neonates in different groups were subjected to ANOVA followed by multiple comparison tests (Zar 1999). Statistical correlation between the circulatory concentrations of VEGF antigen and the Mab in animals of groups 2-5 was examined using standard SPSS v. 10.0.1 statistical analysis software.

\section{Results}

\section{Pregnancy outcome}

Table 1 provides a summary of the data obtained in the pregnancy outcome of monkeys in groups $1-5$ following s.c. injection of isotype-matched mouse $\lg \mathrm{G}$ and antiVEGF Mab. Although there was an apparent decline in the number of mCG-positive pregnancy cycles in groups treated with anti-VEGF Mab in groups 2-4 (12 pregnancies from 20 animals) compared with control animals (six pregnancies from eight animals), this difference was statistically not significant $(P<0.4)$. Similarly, there was statistically no significant $(P<0.2)$ change in the number of successful term pregnancy in animals of groups 2-4 (9 out of 20 animals) compared with the control group. However, administration of antiVEGF Mab to animals on days 5 and 10 after ovulation at $10 \mathrm{mg}$ doses on each day as in group 5 resulted in significant inhibition of establishment of pregnancy as marked by mCG positivity $(P<0.02)$ and term pregnancies $(P<0.01)$ when compared with that found in the control group of animals injected with isotype-matched IgG at same dosage and schedule. Collectively, antiVEGF Mab administration in groups 2-5 resulted in a significant $(P<0.04)$ decline in the number of term pregnancies (9 out of 28 animals), however, with no significant $(P<0.2)$ change in total number of mCGpositive pregnancy cycle when compared with controltreated animals (group 1).

As shown in Table 1, 4 out of 13 pregnant animals from anti-VEGF Mab-treated groups had pregnancy loss at different time points of pregnancy. However, the 30\% abortion rate in anti-VEGF Mab-treated animals was statistically not significant $(P<0.4)$ when compared with the cumulative abortion profile $(22 \%)$ in our monkey colony. Three cases of abortion were observed between days 133 and 139 of gestation (Table 1) and these females exhibited failure to establish implantation stage rise in serum $P$ levels as shown in Fig. 1J. As expected, the body weights $(236.7 \pm 28.9 \mathrm{~g})$ and crown-rump $(C-R)$ lengths $(16.3 \pm 1.5 \mathrm{~cm})$ of aborted fetuses were significantly $(P<0.001)$ lower than the body weights $(435.6 \pm 63.2 \mathrm{~g})$ and $\mathrm{C}-\mathrm{R}$ lengths $(21.5 \pm 1.7 \mathrm{~cm})$ of neonates from all the groups, however, no gross physical abnormality was observed in the aborted fetuses.

The gestation lengths for live births in all the groups ranged between 157 and 182 days, and there was no 

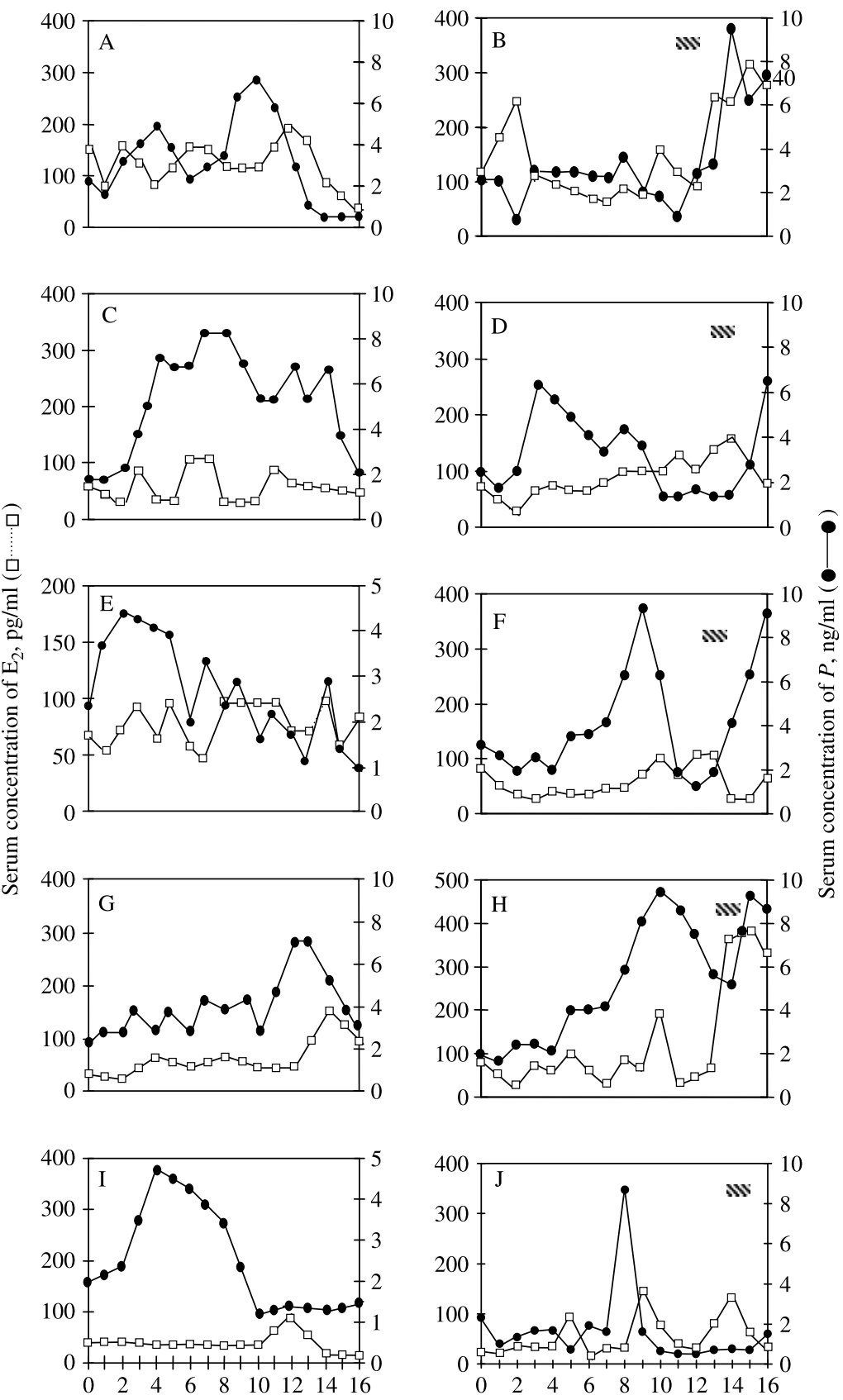

Days after ovulation
Figure 1 Serum profiles of estradiol-17 $\beta, E_{2}$ (blank square) and progesterone, $P$ (solid circle) in non-pregnant $(A, C, E$, $\mathrm{G}$, and $\mathrm{I}$ ) and pregnant (B, D, F, H, and $\mathrm{J}$ ) animals from groups 1 ( $A$ and $B), 2$ (C and $D), 3$ ( $E$ and $F), 4(G$ and $H)$, and 5 ( $($ and $\mathrm{J})$. The first day of $\mathrm{mCG}$ detection in the circulation (hatched bar) is shown. The details of different treatment groups are given in Table 1. marked change in the gestation length between controland anti-VEGF Mab-treated groups. Although neonates from anti-VEGF antibody-treated mothers showed a tendency of lower body weights (380-450 g) when compared with neonates from control-treated mothers (500-520 g), the difference was not significant.

Anti-VEGF Mab or control IgG exposure during the pre- and peri-implantation stages did not affect the length of the luteal phase (26-32 days) in monkeys that remained non-pregnant in the treatment cycles (Table 1).

\section{Serum $E_{2}, P, m C G$, and VEGF}

Figure 1 shows the representative serum profiles of $E_{2}$ and $\mathrm{P}$, and the day of first $\mathrm{mCG}$ detection in the animals following antibody injection under the different treatment schedules detailed in Table 1. Despite differences in serum profiles for these hormones in individual animals, analyses of $A \cup C s$ for $E_{2}$ and $P$ during the luteal phase showed no difference among groups $(P<0.3)$. Interestingly, three cases of abortion between days 135 and 139 showed failure in serum progesterone rise 
during implantation (Table 1 and Fig. 1J). Evidently, the sample size $(n=3)$ is too small to make any comment. Serum mCG was detected in all pregnant monkeys between days 12 and 18 after ovulation. An analysis of the data of AUCs for free VEGF antigen in serum samples of animals of groups $1-5(n=36)$ revealed no significant change in AUCs for VEGF antigen between the pregnant animals from the control treatment $(2177.2 \pm 229.7 \mathrm{pg} /$ $\mathrm{ml}$ per day) group (group 1) and the non-pregnant

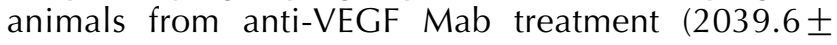
$247.3 \mathrm{pg} / \mathrm{ml}$ per day) groups (groups $2-5$ ). The concentrations of free VEGF were marginally higher $(P<0.05)$ in serum samples of pregnant animals exposed to antiVEGF Mab (3783.2 $\pm 278.6 \mathrm{pg} / \mathrm{ml}$ per day) compared with the antigen concentration $(2177.2 \pm 229.7 \mathrm{pg} / \mathrm{ml}$ per day) in pregnant animals exposed to isotypematched IgG (group 1).

\section{Serum profiles and clearance kinetics of mouse IgG}

Table 3 shows serum profiles and clearance kinetics of mouse IgG respectively, in monkeys belonging to groups $2-5$. As expected, there was a clear increase in serum mouse IgG after each injection. A single s.c. injection of anti-VEGF Mab irrespective of its dose resulted in maximum level of antibody being reached between 1.3 and 2.3 days in animals of groups 2-4. In animals of group 5 injected s.c. twice $(10+10 \mathrm{mg})$ with anti-VEGF Mab on days 5 and 10 after ovulation, maximal levels in sera occurred a week after the first injection. The $C_{\max }$ varied from 2.3 to $4.6 \mu \mathrm{g} / \mathrm{ml}$ in monkeys exposed to $10 \mathrm{mg}$ anti-VEGF Mab. The mean resident time (MRT) was 3.2-5.5 days. No significant difference was obtained between the clearance rates $(k)$ among the different treatment groups. Analyses of AUCs for Mab concentration in sera of animals receiving $20 \mathrm{mg}$ anti-VEGF Mab in group 3 showed significantly higher values when compared with the Mab concentration in animals in groups 2 and $4(P<0.01)$ that had received $10 \mathrm{mg} \mathrm{Mab,}$ and with animals of group $5(P<0.02)$ administered with $10+10 \mathrm{mg}$ Mab against VEGF. Statistically no correlation was found between the circulatory concentrations of VEGF antigen and the Mab in animals of groups 2-5.

\section{Histological characteristics of primary implantation sites and endometrial samples following exposure to mouse antibody}

In order to examine the implantation sites and endometrial histology of animals treated with either isotypematched mouse IgG or anti-VEGF Mab, additional number of animals were treated identically to groups 1 and 5 as shown in Table 1 and primary implantation sites and/or endometrial samples were collected on day 13 after ovulation. Of samples collected from eight mated animals exposed to control mouse IgG on days 5 and 10 after ovulation (like group 1, Table 1), seven samples showed typical primary implantation sites (Fig. 2A), and one sample revealed late secretory stage histology. Typical lacuna stage implantation sites exhibited embryonic disk with secondary yolk sac development typical of a stage in which cytokeratin-positive trophoblast cells blocked arterioles, extensive plaque acini ( $\mathrm{pl}$ ) flanked area enclosing embryonic disk, glands showed hypertrophied features, and dilated blood vessels were abundant at sites of implantation (Fig. 3A and E).

In endometrial samples collected on day 13 after ovulation from eight mated animals exposed to antiVEGF Mab (10 mg each day) on days 5 and 10 after ovulation (like group 5 in Table 1), only one sample exhibited clear-cut blastocyst implantation (Fig. 2B), while one sample revealed typical late secretory stage histology (Fig. 2D). The primary implantation site of the implantation stage sample from the anti-VEGF Mab treatment group showed highly superficial embryo implantation, with small chorionic diameter (Fig. 2B). Based on serial sectioning of the primary implantation site, a small area of embryonic cells were located within the embryonic cavity without any distinctive organization in the formation of embryonic disk; lacunae showed extensive vascular congestion with disruption of lacunar septae (Fig. 2B); extensive cytokeratin-positive pl (Fig. 3B) and dilated blood vessels (Fig. 3F) were, however, seen at the site of implantation. Other six endometrial samples retrieved after VEGF Mab treatment showed epithelial plaque response (Fig. 2C) and scattered cytokeratin-positive trophoblast cells adjoining blood vessels (Fig. 3C and G).

Table 3 Serum profiles and clearance kinetics of monoclonal antibody following s.c. administration.

\begin{tabular}{|c|c|c|c|c|}
\hline \multirow[b]{2}{*}{ Parameter } & \multicolumn{4}{|c|}{ Treatment (Group number) } \\
\hline & $\begin{array}{l}10 \text { mg Mab on day } \\
5 \text { p.ov. (Group 2) }\end{array}$ & $\begin{array}{l}20 \text { mg Mab on day } \\
5 \text { p.ov. (Group 3) }\end{array}$ & $\begin{array}{l}10 \text { mg Mab on day } \\
10 \text { p.ov. (Group 4) }\end{array}$ & $\begin{array}{c}10 \mathrm{mg} \text { Mab on days } \\
5 \text { and } 10 \text { p.ov (Group 5) }\end{array}$ \\
\hline Clearance rate constant, $k$ & $0.2 \pm 0.1$ & $0.3 \pm 0.2$ & $0.3 \pm 0.2$ & $0.4 \pm 0.3$ \\
\hline Time to reach maximal concentration, $T_{\max }$ (days) & $1.3 \pm 0.7$ & $1.3 \pm 0.4$ & $2.3 \pm 0.6$ & $7.0 \pm 1.1$ \\
\hline Concentration at maximal level, $C_{\max }(\mu \mathrm{g} / \mathrm{ml})$ & $4.3 \pm 1.8$ & $11.9 \pm 7.2$ & $2.3 \pm 0.9$ & $4.6 \pm 1.4$ \\
\hline Area under curve, AUC ( $\mu \mathrm{g} / \mathrm{ml}$ per day) & $28.6 \pm 10.3^{+}$ & $58.4 \pm 10.3$ & $21.6 \pm 5.1^{+}$ & $34.7 \pm 10.9 *$ \\
\hline
\end{tabular}

p.ov., after ovulation. Results are shown as means \pm s.D. ${ }^{*} P<0.01,{ }^{\dagger} P<0.02$ compared with Group 3. 

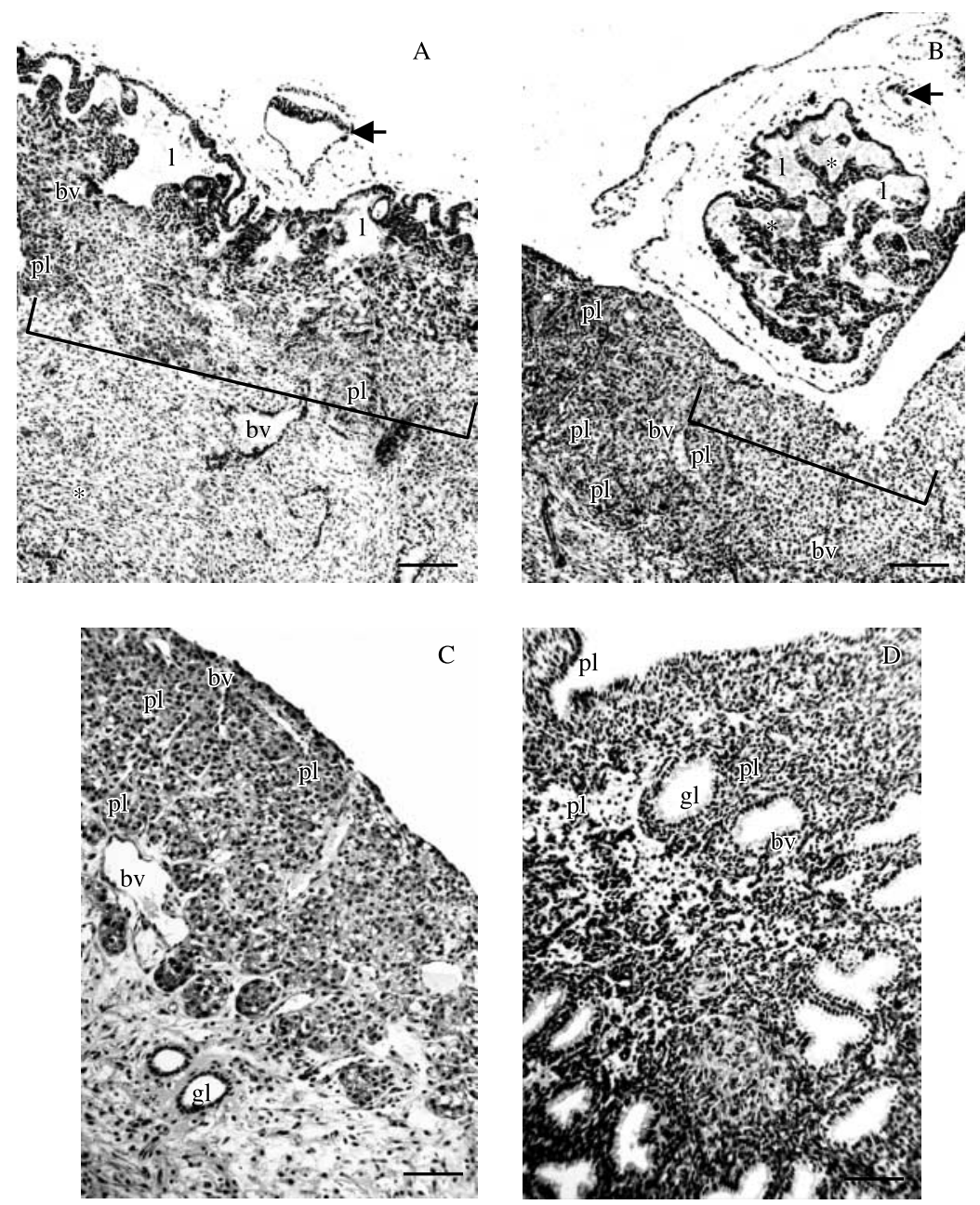

Figure 2 Histology of primary implantation sites collected on day 13 post-ovulation from rhesus monkeys treated with control IgG (A) or anti-VEGF Mab (B-D) on days 5 and 10 post-ovulation. In control IgG-treated sample (A), well-developed plaque acini (pl) flank the primary lacuna stage implantation site, cytotrophoblast cells enclose lacunae (I), extensive trophoblast plate region (bracket) below the embryonic disk (arrow). In anti-VEGF Mab-exposed sample (B), a superficially located primary implantation site shows plaque acini (pl) flanking dilated blood vessels (BV), highly scattered cytotrophoblast cells within a shallow trophoblast plate (bracket); chorion membrane enclosing cytotrophoblast cells with disrupted lacunar septae and extensive vascular congestion (asterisk) are seen; embryonic cells show clear lack of organization in forming putative embryonic disk (arrow). In antiVEGF Mab-exposed samples (C and D), small glands (gl), typical plaque acini (pl), and scattered cytotrophoblast adjoining superficial dilated venules (BV) are found $(C)$; late secretory stage histological features evident with effete glands ( $\mathrm{gl}$ ) within moderately edematous mucosal ground substance (D). Bars $=100 \mu \mathrm{m}$.

\section{Immunolocalization of VEGF, FLT-1, KDR, PECAM, and NCAM}

We examined the distribution of immunoreactive VEGF, FLT-1, and KDR in endometrial samples collected from animals that were treated with control $\lg G(n=7)$ and anti-VEGF Mab $(n=7)$; as described above, these samples did not exhibit typical late secretory changes. VEGF immunoreactivity in cytotrophoblast cells lining lacunae and in cytotrophoblast cell columns was markedly lower in implantation stage tissue from antiVEGF Mab-exposed animal (Fig. 4E and F) when compared with animals exposed to IgG (Fig. 4A and B). In control IgG-exposed animals, cells of embryonic disk, cytotrophoblast cells, cell columns, and syncytiotrophoblast cells were immunopositive for KDR (Fig. 4C), while FLT-1 expression was found primarily in syncytiotrophoblast cells (Fig. 4D). Following antiVEGF Mab exposure, trophoblast cells showed very low immunostaining for KDR (Fig. 4G) and FLT-1 (Fig. 4H), however, these cells were immunopositive for both cytokeratin (Fig. 3B and C) and PECAM (Fig. 5E, F $F_{1}, F_{2}$ and I). In the maternal compartment of anti-VEGF Mab- exposed animals, VEGF expression (Fig. 4E, F and I), expression for KDR (Fig. 4G and J), and FLT-1 (Fig. 4H and $\mathrm{K}$ ) in $\mathrm{pl}$, gland, and stromal cells were comparable with that found in primary implantation sites in IgGexposed animals (Fig. 4A-D). Immunoreactivity for NCAM was predominantly present in syncytiotrophoblast cells, invasive extravillous (interstitial) trophoblast cells, endothelial, and endovascular trophoblast cells (Fig. 5C and D), and these cells were also immunopositive for PECAM (Fig. 5A and B). In lacuna stage samples obtained after control IgG treatment, cytotrophoblast cells, endometrial glands, and stromal cells were negative for NCAM, however, large endometrial granulocytes surrounding glands and spiral arterioles were immunopositive for NCAM (Fig. 5K). There was no distinctive staining for NCAM in trophoblast cells of the primary implantation site recovered from anti-VEGF Mab-exposed animal (Fig. 5G- $\mathrm{H}_{2}$ ), except for a few trophoblast cells lining chorion (Fig. $5 \mathrm{H}_{1}$ ). Large endometrial granulocytes adjoining $\mathrm{pl}$ of the same section and in samples in which only pl were obtained showed distinctive immunoreactivity for NCAM (Fig. 5J). 

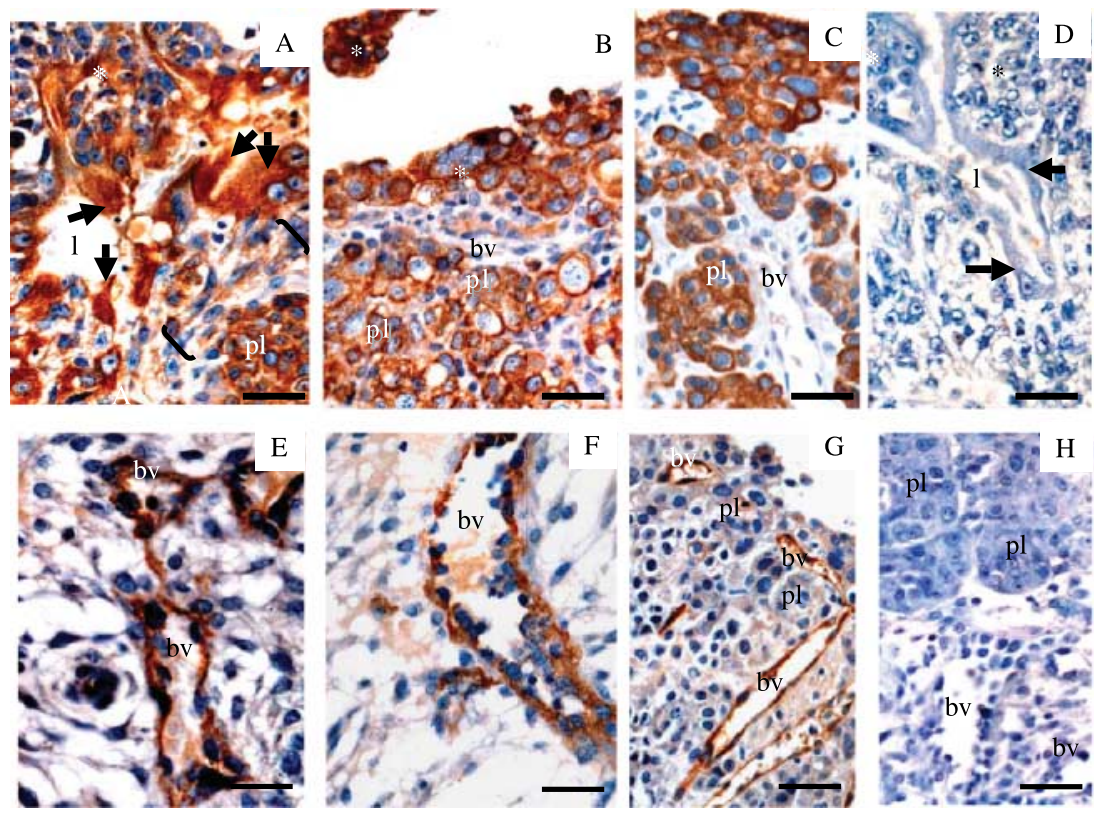

Figure 3 Immunohistochemical localization of cytokeratin (A-C), von Willebrand factor (vWF), (E-G) in primary implantation sites obtained on day 13 post-ovulation from animals treated with control IgG ( $A$ and $E$ ) or anti-VEGF Mab (B and F), and in endometrial samples collected on day 13 postovulation from anti-VEGF Mab-treated animals (C and G). Cytokeratin immunostaining detected in syncytiotrophoblast cells (arrows) lining lacunae (I), cytotrophoblast cells of cell columns $(*)$, invasive cytotrophoblast cells (brackets) adjoining immunostained plaque acinar cells (pl) (A). Cytotrophoblast cells within chorion membrane $(*)$, chorionic plate, and plaque cells showed immunopositive staining for cytokeratin (B). Strong immunostaining for vWF found in endothelial cells lining dilated venules (bv) (E and F). Cytokeratin-positive plaque cells (pl), (C) and vWF immunostaining of blood vessels (bv), (G) found in endometrial samples collected on day 13 post-ovulation from anti-VEGF Mab-treated animals. Control immunohistochemistry of primary implantation site samples showing trophoblast cell columns $\left(^{*}\right)$, syncytiotrophoblast (arrow) lining lacunae (I) following incubation in medium lacking primary antibody for cytokeratin (D), and following incubation in medium lacking primary antibody for vWF $(\mathrm{H})$ showing plaque acinar cells $(\mathrm{pl})$ adjoining dilated blood vessels. Bars $=15 \mu \mathrm{m}$.

PECAM expression in the maternal endometrium was not discernibly affected by anti-VEGF Mab treatment (Fig. 5E, $F_{2}$ and $\mathrm{I}$ ).

\section{Discussion}

In the present study, we have examined the hypothesis whether immunoneutralization of VEGF-A during the receptive preparation of endometrium (day 5 after ovulation) and/or the implantation window (day 10 after ovulation) of gestational cycle affects embryo implantation in the rhesus monkey. In addition, we have avoided applying multiple injections around the time of implantation based on the rationale that such treatment might markedly suppress ovarian function. Systemic injection of anti-VEGF mouse Mab during the receptive and implantation stages of gestation inhibited blastocyst implantation in the rhesus monkey. In addition, in animals treated with anti-VEGF Mab, the expression of both VEGF and its receptors, KDR and FLT1 , exhibited changes in expression in early conceptus tissue suggesting a complex involvement of VEGF in both blastocyst implantation and placental development (Ghosh et al. 2000, Demir et al. 2004). Thus, the results from the present study indicate that VEGF plays a critical physiological role in the process of implantation and placentation in primates. The observation of the present study corroborates well with our earlier pilot study (Ghosh \& Sengupta 2005).

Contrary to our observations, Rowe et al. (2002) observed that anti-VEGF Mab administration via i.v. route on days $0-10$ of luteal phase to marmosets did not affect the pregnancy rate, although plasma progesterone secretion was markedly suppressed compared with animals exposed to mouse $\gamma$-globulin during the same period. We believe that the observed differences in the results of pregnancy outcome after anti-VEGF Mab administration between marmosets and rhesus monkeys arise from the difference in the process of blastocyst implantation in these species. In the marmoset, there is a prolonged period of time when the implantation site expands in the plane of uterine epithelium (trophoblast plate stage) with fusion of syncytiotrophoblast with uterine epithelial cells, but even at day 31 after ovulation syncytiotrophoblast cells do not breach maternal blood vessels; uterine blood vessels are invaded only around days 45-60 of gestation by trophoblast cells expressing FLT-1 (Enders \& Lopata 1999, Wulff et al. 2002, Rowe et al. 2003). In contrast, in the macaque and the baboon, soon after embryo attachment, there is invasion of maternal blood vessels around days 12 of gestation by trophoblast cells similar to the human (Enders \& Schlafke 


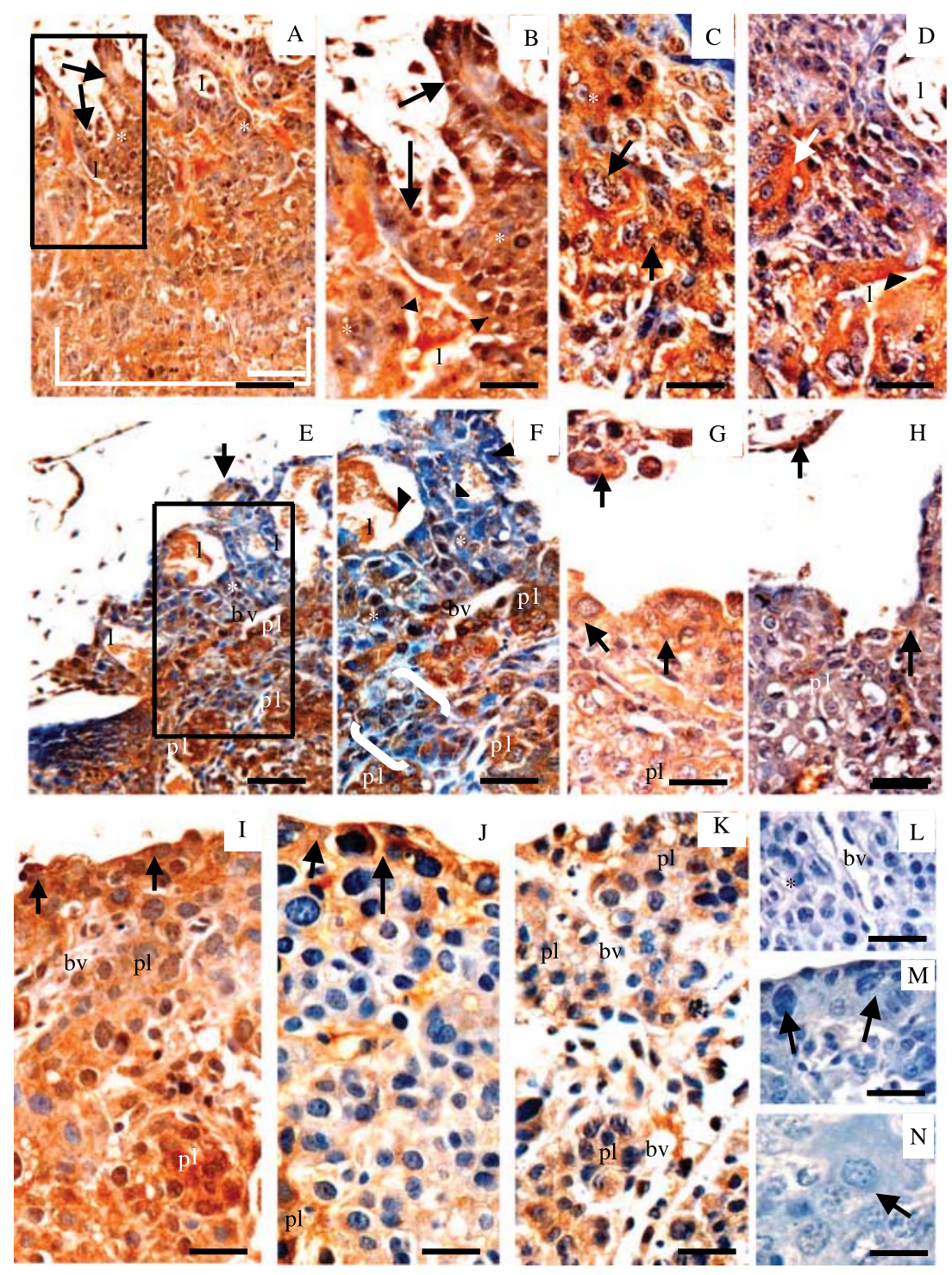

Figure 4 Immunohistochemical localization of $\operatorname{VEGF}(\mathrm{A}, \mathrm{B}, \mathrm{E}, \mathrm{F}$, and I), KDR (C, G, and J), and FLT-1 (D, H, and K) in primary implantation sites obtained on day 13 post-ovulation from animals following treatment with control IgG (A-D) or anti-VEGF Mab (E-H) and in day 13 post-ovulation endometrial samples of anti-VEGF Mab treatment (I-K). Strong immunoprecipitation of VEGF protein found in trophoblast cells within the chorionic plate, in cell columns $\left({ }^{*}\right)$, in cells lining embryonic cavity (arrows), and lacunae (I) (A); inset in A is shown in B. On the other hand, there is absence of VEGF immunostaining in cytotrophoblast cells of cell columns $(*)$, in syncytiotrophoblast lining lacunae (arrow-heads), in invasive trophoblast cells (brackets) (E and F). VEGF immunostaining is, however, detected in plaque acini ( $\mathrm{pl}$ ), endothelial cells lining dilated blood vessels (bv) (E); inset is shown in F. Immunopositivity for KDR (C) is seen in cytotrophoblast cells of cell columns $\left(^{*}\right)$ and in extravillous cytotrophoblast cells at base of column (arrows), while FLT-1 protein immunoprecipitation (D) is found in syncytiotrophoblast cells $\left(^{*}\right)$ lining lacunae in implantation sites from IgGexposed animals. Generally low expression of KDR $(\mathrm{G})$ and FLT-1 $(\mathrm{H})$ in trophoblast cells (arrows) and in plaque acinar cells (pl) within trophoblast plate region of the primary implantation site from anti-VEGF Mab-treated animal. In endometrial samples from anti-VEGF Mab-treated animals, VEGF (I), KDR (J), and FLT-1 (K) immunostaining found in plaque acinar cells (pl) adjoining blood vessel (bv), stromal cells, and in few trophoblast cells (arrows) found in luminal border. Control immunochemistry of primary implantation site samples, trophoblast cell column $(*)$ adjoining blood vessel (bv) incubated with immunoadsorbed primary antibody against VEGF-A protein with recombinant human antigen, $\mathrm{VEGF}_{165}(\mathrm{~L})$; trophoblast cells (arrows) of sample incubated in medium lacking primary antibody for KDR (M); syncytiotrophoblast (arrow) showing no immunoprecipitation for FLT-1 following incubation of sample in medium lacking primary antibody for FLT-1 (N). Bars =15 $\mu \mathrm{m}(\mathrm{B}-\mathrm{D}$ and F-N), $50 \mu \mathrm{m}(\mathrm{A})$, and $100 \mu \mathrm{m}(\mathrm{E})$.

1986). Thus, it is possible that the timing of VEGF immunoneutralization in the marmoset in the luteal phase of mated cycle was inadequate to block VEGFinduced paracrine actions on trophoblast cell invasive functions necessary for pregnancy establishment. In fact, the results of the present study also indicate that the timing of anti-VEGF Mab administration is important in efficacious inhibition of pregnancy in rhesus monkeys. For example, in pregnancy outcome experiment, administration of $10 \mathrm{mg}$ anti-VEGF Mab on days 5 and 10 after ovulation in eight animals yielded no viable pregnancy, although one animal exhibited mCG on day 18 after 


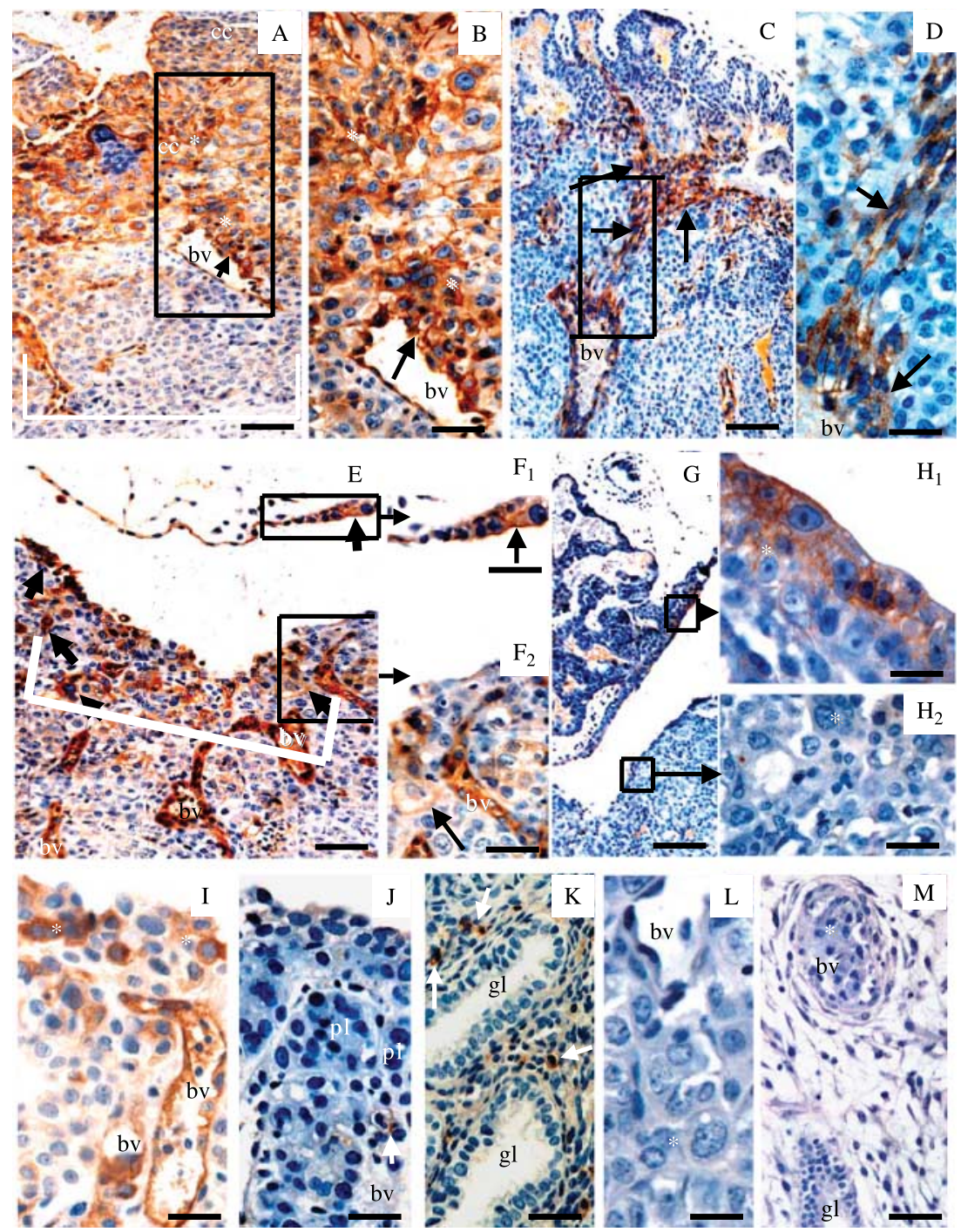

Figure 5 Immunohistochemical localization of $\operatorname{PECAM}\left(A, B, E, F_{1}, F_{2}\right.$, and I) and NCAM $\left(C, D, G, H_{1}, H_{2}\right.$, J, and K) in primary implantation sites obtained on day 13 post-ovulation from animals following treatment with control IgG (A-D and K) or anti-VEGF MAb (E-H $\left.{ }_{2}\right)$ and in day 13 postovulation endometrial samples after anti-VEGF Mab treatment ( $\mathrm{I}$ and $\mathrm{J}$ ). Strong immunoprecipitation of PECAM protein is seen in trophoblast cells of cell columns (cc), in invasive trophoblast cells $\left({ }^{*}\right)$ within the chorionic plate, and in endothelial cells (arrows) lining dilated blood vessel (bv); inset in A is shown in B. In implantation site from anti-VEGF Mab-treated animal, shallow trophoblast plate (bracket) shows immunopositive staining for PECAM in endothelial cells lining dilated blood vessels (bv) and in trophoblast cells (arrows) (E); insets in E are shown in $F_{1}$ and $F_{2}$. NCAM protein immunoprecipitation found in invasive trophoblast cells (arrows) at the feto-maternal border, in endovascular trophoblast cells lining dilated blood vessel (bv) of implantation site sample from an IgG-treated animal (C); inset in C is shown in D; NCAM immunostaining also found in large granulated lymphocytes (arrows) adjoining glands (gl), (K). In anti-VEGF Mab-exposed animal, NCAM immunostaining is not evident in trophoblast cells $(\mathrm{G})$ except for few trophoblast cells lining chorion $\left(\mathrm{H}_{1}\right)$ or in maternal cells $\left(\mathrm{H}_{2}\right)$ of implantation stage sample. In endometrial samples from antiVEGF Mab-treated animals, PECAM immunostaining clearly detected in trophoblast cells adjoining luminal border $(*)$, in endothelial cells of dilated blood vessels (bv) (I); NCAM immunostaining seen in large endometrial granulated lymphocyte adjoining blood vessel (bv) (J). Control immunochemistry of primary implantation site samples of IgG-exposed animal showing absence of immunoprecipitation in endothelial cells of blood vessel (bv), in endovascular cytotrophoblast cells $\left({ }^{*}\right)$, in gland ( $\left.\mathrm{gl}\right)$ following incubation in medium lacking primary antibody for PECAM (L) and $\operatorname{NCAM}(\mathrm{M})$. Bars $=15 \mu \mathrm{m}\left(\mathrm{B}, \mathrm{D}, \mathrm{F} 1, \mathrm{~F} 2, \mathrm{H}_{1}-\mathrm{J}\right.$, and L), $50 \mu \mathrm{m}(\mathrm{E}$ and $\mathrm{K}), 100 \mu \mathrm{m}(\mathrm{A}, \mathrm{C}$, and $\mathrm{G})$, and $250 \mu \mathrm{m}(\mathrm{M})$.

ovulation; similar results were obtained in another set of eight animals that were treated with same regimen of anti-VEGF Mab followed by collection of uteri on day 13 after ovulation for histology and immunohistochemistry.

Previously, studies with rodent models have shown that VEGF action is critical for blastocyst implantation, since timed administration of antibody against VEGF resulted in reduced numbers of implantation sites and inhibition of uterine vascular permeability (Rabbani \& Rogers 2001, Rockwell et al. 2002). However, there was a possibility that inhibition of VEGF action might have affected ovarian steroid synthesis in these studies (Kashida et al. 2001, Rockwell et al. 2002). In a preclinical safety study using cynomolgus monkeys, it has 
been observed that administration of recombinant humanized Mab against VEGF for 4 or 13 weeks at twice weekly doses of 10 and $50 \mathrm{mg} / \mathrm{kg}$ resulted in defective corpora lutea formation (Ryan et al. 1999). In the present study, however, the systemic administration of anti-VEGF Mab in the rhesus monkey did not result in any apparent inadequacy in ovarian function. This is in contrast to the observed pregnancy inhibition following administration of antibody to VEGF-receptor 2 in mice that was associated with compromised ovarian function as marked by a significant fall in circulatory progesterone concentration and administration of progesterone protected the antibody-treated animals from pregnancy loss (Pauli et al. 2005). In the present study, there was no apparent difference in serum $\mathrm{E}_{2}$ or $\mathrm{P}$ levels between pregnant animals following anti-VEGF Mab and those following control IgG injection. This is critical, since it indicates that the effects on pregnancy rates in this study might have resulted from local inhibition of VEGF action in the endometrium and/or developing conceptus. Other groups have observed in the rhesus monkey that systemic injection of anti-VEGF antibody on day 3 after ovulation did not result in significant change in serum progesterone levels (Xu et al. 2005) and such an antibody (AA98) preferentially binds to the newly formed blood vessels at the feto-maternal interface of the implantation site (Liu et al. 2005). It is possible that the sensitivity of blood vessels to VEGF withdrawal depends on their degree of vascular maturation (Otani et al. 1999). We speculate that if anti-VEGF Mab is given at the time of and immediately after ovulation, while vascularization of the corpus luteum is occurring as in the case of the cynomolgus experiment (Ryan et al. 1999), the vessels would be susceptible to disruption and ovarian steroid production would be affected (Zimmerman et al. 2001). On the other hand, if VEGF action is neutralized after the corpus luteum has vascularized as in the present study, no significant effect on ovarian steroid production may be seen due to the existence of a sufficient local cytokine network (Otani et al. 1999), while newly forming blood vessels at feto-maternal interface become more vulnerable (Liu et al. 2005). This possibility is also further substantiated by our observation that the serum concentrations of free VEGF were generally higher in pregnant animals exposed to anti-VEGF Mab compared with that in non-pregnant and control pregnant animals. Although the physiological basis and significance of higher serum VEGF in the antibody-treated pregnant monkeys is not known, it may be speculated that the animals that could mount rebound increase in antigen after antibody treatment are less vulnerable to pregnancy loss after antibody administration.

VEGF $\mathrm{mRNA}$ and protein expression are elevated in mid-secretory stage of endometrium with increased protein secretion in the primate (Charnock-Jones et al. 1993, Li et al. 1994). Pregnancy failure due to endometrial insufficiency, a block in pre-implantation embryo development and viability in the rhesus monkey after early luteal phase mifepristone exposure is associated with low VEGF expression and secretion (Ghosh et al. 1998). Furthermore, a dialogue between embryo and endometrium is considered essential for blastocyst implantation and may involve the synthesis and secretion of hCG and VEGF from embryonic and maternal sources respectively (Licht et al. 2001). Several reported studies earlier indicated a possible role of VEGF in the regulation of invasive and migratory capacities of early placental trophoblasts (Lash et al. 2003, Anteby et al. 2004). Thus, it appears that the observed high incidence of pregnancy failure following anti-VEGF Mab treatment might have been precipitated by inadequate trophoblast invasion and placental formation associated with their lower expression of VEGF, KDR, and FLT-1. However, it is not evident why conceptus tissues were primarily affected, while maternal endometrium did not show any clear-cut change in histology and in immunopositive profiles for proteins VEGF, KDR, and FLT-1 following anti-VEGF Mab treatment. It becomes yet more complex with the recognition of the fact that administered antibody to a pregnant animal tends to remain in the maternal compartment and generally does not reach to the embryonic tissue (Pauli et al. 2005). It would be interesting to investigate a comparative differential display in the protein-protein interactions using proteomics approach in the maternal endometrium between control and anti-VEGF Mab treatment, rather than the functional cluster of VEGF action associated proteins only (Graham et al. 2005).

Our data also support a role for NCAM or CD56 in trophoblast invasion (Blankenship \& King 1996, Slukvin et al. 2000). NCAM is a multifunctional protein and considered as a receptor that responds to both homophilic and heterophilic cues as a mediator of cell adhesion and neural cell migration via two distinct domains for NCAM and heparan sulfate (Hinsby et al. 2004). Trophoblast cell invasion of spiral arterioles is likely to involve migratory and invasive behavior of NCAM-mediated cell-type segregation, involving changes in cadherin-mediated adhesion and cell polarity (Burrows et al. 1994, Blankenship \& King 1996, Proll et al. 1999). In the present study, we observed a clear decline in expression of cell adhesion molecule NCAM and it was associated with shallow uterine invasion and failure to invade spiral arterioles in anti-VEGF Mabexposed animals. In the present study, we also observed that extravillous trophoblast cells and vascular endothelium expressed immunopositive PECAM-1, and that its expression was not markedly modified in anti-VEGF Mab-treated samples. Although there is evidence in the literature to suggest that PECAM-1 expression in conceptus may play important role in embryo development, as well as in trophoblast cell invasion of the spiral arteries (Blankenship \& Enders 1997, Robson et al. 
2001), its actual physiological role has been debated (Lyall et al. 2001).

An important physiological consideration in the present study had been the timing of anti-VEGF Mab treatment for effective pregnancy inhibition. The best opportunity for therapeutic intervention was considered to be the point when pro-inflammatory responses are induced for supporting an evolutive pregnancy with heightened vascular permeability along with an influx at the site of blastocyst implantation of pro-inflammatory blood cells, vasotropic growth factors, such as VEGF and placenta growth factor (PIGF), and pro-inflammatory cytokines, such as leukemia inhibitory factor (LIF), IL- $1 \alpha$, IL-1 $\beta$, and IL-6 (Ghosh et al. 2000, 2004, Sengupta et al. 2003).

Finally, we conclude that inadequate invasion by trophoblast cells following timed systemic mid-luteal phase administration of sufficient amount of murine VEGF Mab results in pregnancy failure. This provides the proof of concept that VEGF action is required for successful blastocyst implantation in the rhesus monkey.

\section{Acknowledgements}

This study was supported by a grant from the WHO-Rockefeller Foundation 'Initiative on Implantation Research'. AS was supported by a Meres Research Studentship from St John's College, Cambridge. The control hybridoma was obtained from Richard Pannell in Dr C Milstein's lab in the Laboratory of Molecular Biology, Cambridge. Both Mab (Mab 518 B7) generated against bovine luteinizing hormone (LH) and polyclonal antiserum against human chorionic gonadotropin (hCG cr-121) were kindly provided by Prof. Bill L Lasley (University of California, Davis, CA, USA). The authors declare that there is no conflict of interest that would prejudice the impartiality of this scientific work.

\section{References}

Ancelin M, Buteau-Lozano H, Meduri G, Osborne-Pellegrin M, Sordello S, Plouet H \& Perrot-Applanat M 2002 A dynamic shift of VEGF isoforms with a transient and selective progesterone-induced expression of VEGF189 regulates angiogenesis and vascular permeability in human uterus. PNAS 99 6023-6028.

Anteby EY, Greenfield C, Natanson-Yaron S, Goldman-Wohl D, Hamani Y, Khudyak V, Ariel I \& Yagel S 2004 Vascular endothelial growth factor, epidermal growth factor and fibroblast growth factor-4 and -10 stimulate trophoblast plasminogen activator system and metalloproteinases-9. Molecular Human Reproduction 10 229-235.

Blankenship TN \& Enders AC 1997 Expression of platelet-endotheial cell adhesion molecule-1 (PECAM) by macaque trophoblast cells during invasion of the spiral arteries. Anatomical Record 247 413-419.

Blankenship TN \& King BF 1996 Macaque intra-arterial trophoblast and extravillous trophoblast of cell columns and cytotrophoblast shell express neural cell adhesion molecule (NCAM). Anatomical Record 245 525-531.

Burrows TD, King A \& Loke YW 1994 Expression of adhesion molecules by endovascular trophoblast and decidual endothelial cells: implications of vascular invasion during implantation. Placenta 15 21-33.
Charnock-Jones DS, Sharkey AM, Rajput-Williams J, Burch D, Schofield JP, Fountain SA, Boocock CA \& Smith SK 1993 Identification and localization of alternately spliced mRNAs for vascular endothelial growth factor in human uterus and estrogen regulation in endometrial carcinoma cell lines. Biology of Reproduction 48 1120-1128.

Demir R, Kayisli UA, Seval Y, Celik-Ozenci C, Korgun ET, DemirWeusten AY \& Huppertz B 2004 Sequential expression of VEGF and its receptors in human placental villi during very early pregnancy: differences between placental vasculogenesis and angiogenesis. Placenta 25 560-572.

Enders AC \& Lopata A 1999 Implantation in the marmoset monkey: expansion of the early implantation site. Anatomical Record 256 279-299.

Enders AC \& Schlafke S 1986 Implantation in non-human primates and in the human. In Reproduction and Development, pp 291-310. Eds WR Dukelow \& J Erwin. Indianapolis: John Wiley.

Ferrara N \& Smith DT 1997 The biology of vascular endothelial growth factor. Endocrine Reviews 18 4-25.

Ghosh D \& Sengupta J 1993 Anti-nidatory effect of a single, early postovulation administration of mifepristone (RU 486) in the rhesus monkey. Human Reproduction 8 352-358.

Ghosh D \& Sengupta J 1998 Recent developments in the endocrinology and paracrinology of blastocyst implantation in the primate. Human Reproduction Update 4 153-168.

Ghosh D \& Sengupta J 2005 Target-oriented anti-implantation approaches for pregnancy interception: experiences in the rhesus monkey model. Contraception 71 294-301.

Ghosh D, Stewart DR, Nayak N, Lasley B, Overstreet JW, Hendrickx AG \& Sengupta J 1997 Serum concentrations of oestradiol-17ß, progesterone, relaxin and chorionic gonadotrophin during blastocyst implantation in natural pregnancy cycle and in embryo transfer cycle in the rhesus monkey. Human Reproduction 12 914-920.

Ghosh D, Lalitkumar PGL \& Sengupta J 1998 Effects of early luteal phase administration of mifepristone (RU486) on leukemia inhibitory factor, transforming growth factor $\beta$ and vascular endothelial growth factor in the preimplantation stage endometrium of the rhesus monkey. Journal of Endocrinology 157 115-125.

Ghosh D, Sharkey AM, Charnock-Jones DS, Dhawan L, Dhara S, Smith SK \& Sengupta J 2000 Expression of vascular endothelial growth factor (VEGF) and placental growth factor (PIGF) in conceptus and endometrium during implantation in the rhesus monkey. Molecular Human Reproduction 6 935-941.

Ghosh D, Bell SC \& Sengupta J 2004 Immunohistochemical localization of insulin-like growth factor binding protein-1 in primary implantation sites and trauma-induced deciduomal tissues of the rhesus monkey. Placenta 25 197-207.

Graham DRM, Elliott ST \& Van Eyk JE 2005 Broad-based proteomic strategies: a practical guide to proteomics and functional screening. Journal of Physiology 563 1-9.

Greb RR, Heikinheimo O, Williams RF, Hodgen GD \& Goodman AL 1997 Vascular endothelial growth factor in primate endometrium is regulated by oestrogen-receptor and progesterone-receptor ligands in vivo. Human Reproduction 12 1280-1292.

Hinsby AM, Berezin V \& Bock E 2004 Molecular mechanisms of NCAM function. Frontiers in Bioscience 9 2227-2244.

Hornung D, Lebovic DI, Shifren JL, Vigne JL \& Taylor RN 1998 Vectorial secretion of vascular endothelial growth factor by polarized human endometrial epithelial cells. Fertility and Sterility 69 909-915.

Kashida S, Sugino N, Takiguchi S, Karube A, Takayama H, Yamagata Y, Nakamura Y \& Kato H 2001 Regulation and role of vascular endothelial growth factor in the corpus luteum during midpregnancy in rats. Biology of Reproduction 64 317-323.

Krussel JS, Casan EM, Raga F, Hirchenhain J, Wen Y, Huang H-Y, Bielfeld P \& Polan ML 1999 Expression of mRNA for vascular endothelial growth factor transmembraneous receptors FLT-1 and KDR and the soluble receptor s-flt in cycling human endometrium. Molecular Human Reproduction 5 452-458. 
Lash GE, Warren AY, Underwood S \& Baker PN 2003 Vascular endothelial growth factor is a chemoattractant for trophoblast cells. Placenta 24 549-556.

Li XF, Gregory J \& Ahmed A 1994 Immunolocalization of vascular endothelial growth factor in human endometrium. Growth Factors 11 277-282.

Licht P, Russu V \& Wildt L 2001 On the role of human chorionic gonadotropin (hCG) in the embryo-endometrial microenvironment: implications for differentiation and implantation. Seminars in Reproductive Medicine 19 37-47.

Liu Y-X, Gao F, Wei P, Chen X-L, Gao H-J, Zou R-J, Siao L-J, Xu F-H, Feng Q, Liu K, et al. 2005 Involvement of molecules related to angiogenesis, proteolysis and apoptosis in implantation in rhesus monkey and mouse. Contraception 71 249-262.

Lopata A 1996 Blastocyst-endometrial interaction: an appraisal of some old and new ideas. Molecular Human Reproduction 2 519-525.

Lyall F, Bulmer JN, Duffie E, Cousins F, Theriault A \& Robson SC 2001 Human trophoblast invasion and spiral artery transformation: the role of PECAM-1 in normal pregnancy, preeclampsia, and fetal growth restriction. American Journal of Pathology 158 1713-1721.

Meduri G, Bausero P \& Perrot-Applanat M 2000 Expression of vascular endothelial growth factor receptors in the human endometrium: modulation during the menstrual cycle. Biology of Reproduction 62 439-447.

Nayak NR \& Brenner RM 2002 Vascular proliferation and vascular endothelial growth factor expression in the rhesus macaque endometrium. Journal of Clinical Endocrinology and Metabolism 87 1845-1856.

Otani N, Minami S, Yamoto M, Shikone T, Otani H, Nishiyama R, Otani T \& Nakano R 1999 The vascular endothelial growth factor/fms-like tyrosine kinase system in human ovary during the menstrual cycle and early pregnancy. Journal of Clinical Endocrinology and Metabolism 84 3845-3851.

Pauli SA, Tang H, Wang J, Bohlen P, Posser R, Hartman T, Sauer MV, Kitajewski J \& Zimmerman RC 2005 The vascular endothelial growth factor (VEGF)/VEGF receptor 2 pathway is critical for blood vessel survival in corpora lutea of pregnancy in the rodent. Endocrinology 146 1301-1311.

Proll J, Blaschitz A, Hartmann M, Thalhamer J \& Dohr G 1999 Human first trimester placenta intra-arterial trophoblast express the neural cell adhesion molecule. Early Pregnancy 2 271-275.

Rabbani ML \& Rogers PA 2001 Role of vascular endothelial growth factor in endometrial vascular events before implantation in rats. Reproduction 122 85-90.

Robson P, Stein P, Zhou B, Schultz RM \& Baldwin HS 2001 Inner cell mass specific expression of a cell adhesion molecule (PECAM1/CD31) in the mouse blastocyst. Developmental Biology 234 317-329.

Rockwell LC, Pillai S, Olson CE \& Koos RD 2002 Inhibition of vascular endothelial growth factor/vascular permeability factor action blocks estogen induced uterine edema and implantation in rodents. Biology of Reproduction 67 1804-1810.
Rowe AJ, Morris KD, Bicknell R \& Fraser HM 2002 Angiogenesis in the corpus luetum of early pregnancy in the marmoset and the effects of vascular endothelial growth factor immunoneutralization on establishment of pregnancy. Biology of Reproduction 67 1180-1188.

Rowe AJ, Wulff C \& Fraser H 2003 Localization of mRNA for vascular endothelial growth factor (VEGF), angiopoietins and their receptors during the peri-implantation period and early pregnancy in marmosets (Callithrix jacchus). Reproduction 126 227-238.

Ryan AM, Eppler DB, Hagler KE, Bruner RH, Thomford PJ, Hall RL, Shopp GM \& O'Neill CA 1999 Preclinical safety evaluation of rhuMabVEGF, an antiangiogenic humanized monoclonal antibody. Toxicologic Pathology 27 78-86.

Sengupta J \& Ghosh D 2002 Blastocyst-endometrium interaction at implantation in the rhesus monkey. Journal of Reproductive Immunology 53 227-239.

Sengupta J, Dhawan L \& Ghosh D 2003 Immunohistochemical localization of leukemia inhibitory factor, interleukins 1 and 6 at the primary implantation site in the rhesus monkey. Cytokine $\mathbf{2 4}$ 277-285.

Shargel L \& Yu ABC 1999 Applied Biopharmaceutics \& Pharmacokinetics, 4 New Jersey: Prentice-Hall, pp. 608-642.

Sharkey AM, Catalano R, Evans A, Charnock-Jones DS \& Smith SK 2005 Novel antiangiogenic agents for use in contraception. Contraception 71 263-271.

Shifren JL, Tseng JF, Zaloudek CJ, Ryan IP, Meng G, Ferrara N, Jaffe RB \& Taylor RN 1996 Ovarian steroid regulation of vascular endothelial growth factor in the human endometrium: implications for angiogenesis during the menstrual cycle and in the pathogenesis of endometriosis. Journal Clinical Endocrinology and Metabolism 81 3112-3118.

Slukvin II, Lunn DP, Watkins DI \& Golos TG 2000 Placental expression of the nonclassical MHC class I molecule Mamu-AG at implantation in the rhesus monkey. PNAS 97 9104-9109.

Wulff C, Wilson H, Dickson SE, Wiegand SJ \& Fraser HM 2002 Hemochorial placentation in the primate: expression of vascular endothelial growth factor, angiopoietins and their receptors throughout pregnancy. Biology of Reproduction 66 802-812.

Xu F, Hazzard TM, Evans A, Charnock-Jones S, Smith S \& Stouffer RL 2005 Intraovarian actions of anti-angiogenic agents disrupts preiovulatory events during the menstrual cycle in monkeys. Contraception 71 239-248.

Zar JH 1999 Biostatistical Analysis, 4 New Jersey: Prentice-Hall, pp. $177-254$.

Zimmerman RC, Xiao E, Husami N, Sauer MV, Lobo R, Kitajewski J \& Ferin M 2001 Short-term administration of antivascular endothelial growth factor antibody in the late follicular phase delays follicular development in the rhesus monkey. Journal of Clinical Endocrinology and Metabolism 86 768-772.

Received 13 April 2006

First decision 17 May 2006

Revised manuscript received 24 November 2006

Accepted 22 December 2006 